\title{
MODELS OF POLITICAL CYCLES: THE CZECH EXPERIENCE
}

\author{
Radka Štiková*
}

\begin{abstract}
:
This paper studies whether the dynamic behaviour of real GDP, unemployment and inflation is systematically affected by the timing of elections and by changes of government in the Czech Republic. Two basic models of political cycles are tested - political business cycle models and partisan theories. Political business cycle models emphasize the opportunistic behaviour of incumbents who strive to get re-elected regardless of party affiliation. On the other hand, partisan politicians are faithful to their ideological opinions and therefore attract a specific constituency. The tests partly support the opportunistic motives for the behaviour of Czech politicians. On the contrary, suppositions of partisan motives were not proved.
\end{abstract}

Keywords: fiscal policy, political cycle, models of political business cycle, partisan theories

JEL Classification: E-32, E-61, E-62, C-22

\section{Introduction}

2006 was an election year in the Czech Republic. This was reflected in the adoption of a series of household-friendly measures and the further postponement of much needed pension and health reforms. The run-up to the elections saw the approval of "crayon allowances" for the first-graders, a hike in maternity grants, a doubling of family allowances, changes to numerous social benefits, an additional rise in pensions, and so on. The increased burden on the expenditure side in the form of increased mandatory spending coupled with a decreasing tax burden ${ }^{1}$ raised the deficit pressures on Czech public finances. Although the final fiscal outcome in 2007 was significantly better then expected due to very high direct taxes collection, this behaviour of former Czech government could be considered as a typical example of failure of fiscal policy performance.

The fiscal policy motives of incumbents are dealt with in the "political cycle theories", which began to be developed in the 1970s. They crystallized into two main

* Institute of Economic Studies of the Charles University, Prague (radka.stikova@cnb.cz).

The author would like to thank Štěpán Radkovský for valuable comments and suggestions. The views expressed in this paper are entirely those of the author and do not reflect the views of the Institute of Economic Studies of the Charles University. The paper was written with support from the Czech Republic Ministry of Education Grant MSM 0021620841.

1 Corporate income tax rates have been falling since 2004. In 2006, the lowest personal income tax rates were also cut, more goods were transferred to the reduced VAT rate, etc. The only exception to the downward trend are the excise duties, which are generally rising as a result of harmonization with EU legislation. 
groups of theories: the political business cycle theories (also called opportunistic theories) and the partisan theories. Aside from these two main groups of theories, alternative political cycle theories also have started to emerge. Some of the newer approaches, for example, combine selected aspects of the two main theories, because the conclusions of the one cannot usually be fully rejected in favour of the other.

As the economic theories of the motives for incumbents' behaviour have developed, many economists have started to test the theories on empirical data. The first analyses were conducted on post-war data in the USA. A series of similar studies for other developed economies followed. More recently, panel data and suchlike have been applied. Tests have been performed for the presence of political cycles using both macroeconomic variables and fiscal indicators (e.g. public finance deficits, public sector spending, taxes and tax structures). Although the conclusions of such analyses have often been ambiguous, many studies suggest that the partisan motive is stronger. In the case of the new democracies, the presence of political business cycles has also been confirmed using public finance deficits (Brender and Drazen, 2004). ${ }^{2}$ Such cycles are characterized by growing deficits in election years, although only for a few terms of office following the establishment of democracy.

The political business cycle in the Czech Republic has so far been tested to a very limited extent, usually in panel studies. This is due to problems with the existing database, which tends to have short time series subject to frequent major revisions. Moreover, the Czech economy went through a period of transformation in the 1990s, a period linked with numerous structural changes and several specific shocks. Recent political situation and the adoption of a range of populist measures linked with the election year nonetheless indicate a need to look again at the possible motives for politicians' behaviour and the ensuing potential risks. This means more than simply pointing out that most incumbents will probably try to push through popular measures in an attempt to get re-elected. It means examining the extent to which such behaviour affects the Czech economy and the extent to which partisanship can be observed in the behaviour of Czech incumbents.

The aim of this paper is to study the extent to which macroeconomic variables (GDP, unemployment and inflation) are systematically affected in the Czech Republic by the timing of elections and by changes of government. Two basic above mentioned models of political cycles are tested using the relatively traditional method of Alesina and Roubini (1990). We do not intent to explain the procyclicality of fiscal policy in the Czech Republic, since that is by no means related to the political cycle alone. Before the actual testing of the political cycle theories in the Czech economy, the following section briefly describes the major theoretical approaches to this subject.

2 The term "new democracies" here means the states that started to establish democratic systems between the late 1970s and the early 1990s. They include the former Soviet-bloc countries (including the Czech Republic). According to Brender and Drazen, manipulation of the business cycle is possible in such countries because voters are inexperienced with electoral politics or due to the lack of information needed to evaluate fiscal measures. 


\section{Models of Political Cycles}

The economic theory contains two main groups of models that variously explain the motives for politicians' behaviour and how this behaviour affects the business cycle of the country in question, namely the political business cycle models (e.g. Nordhaus, 1975 ) and the partisan models of political cycles (e.g. Hibbs, 1977). The first generation of both types of model was developed in the 1970s, whereas the second dates from the late 1980s and early 1990s. In both generations, the main tool used to express political parties' preferences was the Phillips curve, which plots the negative relationship between inflation and the unemployment rate.

The main difference between the two generations of models, conversely, consists in the nature of the expectations of economic agents. The first generation assumed adaptive expectations (i.e. voters assess incumbents on how output and inflation evolve over their term of office, with the weight of their past observations gradually diminishing over time). The second generation took account of rational expectations (i.e. voters also assess incumbents on their party affiliation, their expected preference between inflation and unemployment - not only at election time - and so on). Following the incorporation of rational expectations these two groups of models were renamed the rational political business cycle models (e.g. Persson and Tabellini, 2000) and the rational partisan models (e.g. Alesina, 1990). In addition, the current theoretical literature dealing with political cycles admits that politicians are guided in their behaviour by a combination of opportunistic and partisan motives simultaneously, i.e. they combine partisan motives with career interests.

The political business cycle (PBC) theories, which are also often referred to as opportunistic models, assume that incumbents attempt primarily to maximize their own popularity and their probability of re-election regardless of party affiliation. Politicians who are in power or have a say in the decision-making process try to manipulate the economy to achieve their goals. Unpopular economic and political measures tend to be introduced very soon after elections, whereas popular measures are planned for just before elections. Incumbents interfere primarily with public spending, which they control directly. These discretionary fiscal interventions in turn affect macroeconomic variables. Every government thus pursues the same policy - stimulating economic performance in the pre-election period (accompanied with upturn in economic growth and lower unemployment), setting off a recession after the elections and preparing favourable conditions for the next pre-election period. The after-election recession is a result of a monetary policy tightening aimed at cutting inflation which rises around the election time and immediately thereafter (as inflation responds with a lag to the pre-electoral economic expansion).

The incorporation of rational expectations into the political business cycle models (to form RPBC models) modifies voters' decisions in elections in the sense that those decisions reflect expectations regarding the future actions of the parties' representatives. In their expectations, voters also take into account politicians' past actions and party affiliation, i.e. their expected preference between inflation and unemployment, etc. To some extent, then, the RPBC models can take account of partisanship in politicians' behaviour. Politicians are interested in their careers but simultaneously usually represent a particular political party, and voters rate them according to this 
affiliation. Owing to the existence of information asymmetry, under rational expectations one can expect voters to be swayed to some extent by an intentional stimulation of the economy in the pre-election period. However, cycles should be shorter and less regular than in the case of the PBC models. In the RPBC models, the relationship between output and the election date is not entirely clear, as efforts by incumbents to manipulate inflation and unemployment can imply either upswings or downswings in output.

More recent studies examining the RPBC theories emphasize the role of signalling (Rogoff and Sibert, 1988; Rogoff, 1990), adding that the political cycle can be observed more in the evolution of fiscal policy, as the impact on output and inflation is limited. As in the traditional RPBC models, the political cycle in public finances is driven by temporary information asymmetries between politicians and the electorate. The key assumption is that the government has information on its performance (e.g. in the area of public finances) in advance of the voters and can therefore try to "signal" its success before the elections. All depends on the incumbent's ability to exploit the information asymmetry to manipulate rational voters, who have certain fiscal policy expectations and preferences and assess the incumbents' competence.

However, many economists question the hypothesis that incumbents tend to influence the economy opportunistically over the business cycle, and instead emphasize the "partisan" characteristics of their behaviour (the "partisan" theories of the political cycle). The partisan theories (PTs) assume that politicians are faithful to their party's policy goals (expressed, for instance, in terms of a particular combination of the inflation rate and the unemployment rate) and thus reflect the interests of a specific constituency. It is traditionally assumed that left wing parties are more concerned with tackling unemployment, while right wing parties generally attach more weight to reducing inflation, even at a cost of higher unemployment. The first generation of partisan models assumed that the impacts on output and employment in relation to an incumbent's political orientation are constant over its term of office.

Under the rational partisan theories (RPTs), each voter realizes that different political parties pursue different goals and votes for the party that best reflects his own preferences. Assuming slow wage adjustment, changes in the inflation rate associated with changes of government cause real economic activity to deviate temporarily from its natural level. Following the transitory adjustment period, the level of economic activity should be independent of the government's political orientation. After economic activity returns to its natural level the rate of inflation should remain higher under a left wing government than under a right wing government. Voter rationality thus causes individual deviations in real variables to return to their natural level (although this is not the case with inflation). The government can achieve deviations in real variables only in the short run and only at the start of its term of office. In the longer run, voter rationality prevents such deviations. A change of government towards the right therefore leads to an only temporary fall in output growth. The opposite applies in the case of a left wing government, which is more concerned with supporting economic activity and reducing unemployment at the cost of rising inflation. As a consequence of the left wing government's efforts to generate an economic expansion - an expansion which is, however, only temporary - the economy thus ends up in a sub-optimal 
equilibrium with higher inflation, while output and unemployment return to their natural levels.

Most models of the political cycle based on the aforementioned theoretical approaches assume that the election date is exogenously given. In formulating their own ideas about the form of political cycles, however, some authors have tried, on the basis of empirical observations, to take the possibility of endogenous election timing into account (Ito, 1990). This assumption means that elections can be called at practically any time and the incumbent thus naturally tries to call them when the economy is on the rise. In other words, the better the state of the economy, the higher the chance of elections being called soon. The basic tenet of these theories is that the government has no control of economic activity but tries to capitalize on spontaneous good economic conditions (where the law of the land allows to do it so).

\section{The Method for Testing Political Cycle Theories}

Several approaches can be used to test the political cycle theories. Here we apply the relatively traditional method of Alesina and Roubini (1990), which tracks the impacts of the electoral cycle on real output, unemployment and inflation. The initial assumption is that these variables can be described by an autoregressive process of a particular order. One can then add a political dummy to the autoregressive process to represent the theoretical concept being tested. The general model can be formally written as follows:

$$
y_{t}=\alpha_{0}+\alpha_{1} y_{t-1}+\alpha_{2} y_{t-2}+\ldots .+\alpha_{n} y_{t-n}+\beta P D U M_{t}+\varepsilon_{t},
$$

where $y_{t}$ denotes the time series of one of the tested variables and $P D U M_{t}$ represents a political dummy. The model used is an AR type model requiring stationary time series. If only non-stationary time series are available, they can be stationarized by making certain modifications (e.g. by applying differences). In the case of small open economies it is recommended to include a proxy for the world economy in the model (expressed, for example, in terms of world growth in real output, world inflation, etc.) to control for the effect of the world economy on the domestic economy. ${ }^{3}$ Another proposed method for incorporating the world economy into the model is to express each tested variable as the difference between the domestic variable and a proxy for the world average. This solution can also help to eliminate any problems with non-stationarity of the time series used.

The specification of the order of the autoregressive model depends on the results of standard diagnostic tests. In the estimated model, the statistical significance of including the political dummy is thus tested. One also needs to verify whether the resulting model is specified in accordance with the theory being tested (i.e. whether the coefficients on the political dummies have the right sign).

3 Alesina presents two main arguments for incorporating a world variable into the model. First, the partisan or opportunistic goals of the politicians are likely to be defined in small open economies in relation to the rest of the world. Second, regardless of the politicians' goals, international trade and financial linkages make economies highly interdependent, hence they cannot be treated as independent economies. 
The political business cycle (PBC) models predict a pre-electoral upturn in economic growth and lower unemployment, a rise in inflation around the election time and immediately thereafter and a post-electoral recession, regardless of the incumbent's political orientation. Hence in the case of testing the political business cycle hypothesis, the AR models of GDP and unemployment include a political dummy of +1 in the $\mathrm{N}$ periods preceding an election and in the election quarter and 0 in all other periods. Any length of $\mathrm{N}$ can be chosen, depending on the expected speed of adjustment of the economy. ${ }^{4}$ When testing the PBC theory using inflation, the political dummy is set at +1 in the 4 quarters following an election and in the election quarter and 0 otherwise.

As the partisan theories usually emphasize the direction of the change of government to test their validity a political dummy is applied that differs in value depending on the direction of the change of government. The change in the dummy associated with a change of government is lagged by 1 quarter after the appointment of the new government to account for the period of adjustment that occurs immediately after the change of regime while the new economic policy is implemented. In the case of unemployment a lag of two quarters is more appropriate, as unemployment reacts rather more slowly to changes in government policy.

It is assumed that right wing parties are more focused on low inflation (even at a cost of higher unemployment), while left wing parties are concerned with tackling unemployment (and GDP growth). As the rational partisan theories (RPTs) assume that the incumbent's political orientation has only a transitory impact on GDP and unemployment, in the AR models based on these time series the political dummy is +1 in the $\mathrm{N}$ quarters following a change of government towards the right, -1 in the $\mathrm{N}$ quarters following a change of government towards the left and 0 if the same political party stays in power after the elections. ${ }^{5}$ In the case of testing the partisan political cycle theories (PTs) that do not incorporate rationality, it is assumed that change of government has a permanent impact on output and unemployment and hence the political dummy is +1 in all periods when a right wing government is in office (including the quarter of the change of government) and -1 in all periods when a left wing government is in office. Both theories consider a permanent reaction of inflation to the change of government, so the political dummy has the same profile as the dummy for GDP and unemployment in the case of testing the partisan political cycle theories.

\section{The Political Cycle in Real GDP, Unemployment and Inflation in the Czech Republic}

The Czech Republic is the parliamentary democracy since the fall of the communist regime in November 1989. Thus it has relatively short history of democracy. Apart from major political reforms, the country has passed fundamental economic transformation since then. The Czech economy as a whole underwent significant structural changes to reach a level of standard market economy (as price liberalization, restitution,

\footnotetext{
4 A value in the range of 4-8 is usually recommended, as wage contracts in many countries have a length of 1-2 years (i.e. 4-8 quarters).

5 As in the previous case, the length of $\mathrm{N}$ is usually chosen from the range of 4-8.
} 
privatisation, industrial transformation, structural changes of labour market etc.). These changes are reflected in time series of economic variables.

Parliamentary elections traditionally take place once every four years during June. The new government takes office approximately one month later (the exception being the most recent parliamentary elections in 2006, when the lag was much longer). Since the independent Czech Republic was established, parliamentary elections have been held in 1996, 1998, 2002 and 2006. However, in 1993-2006 there was essentially only one change of majority incumbent party - after the elections in 1998. A second such change occurred following the 2006 elections $^{7}$. Both main ruling parties not only implemented their own political programmes, but also had to introduce a series of reforms connected with the transformation of the Czech economy. These reforms were not necessarily fully consistent with the political orientation of the incumbent.

The existence of a political cycle in the Czech Republic has yet to be tested on a broad scale. The aim of this section, therefore, is to apply the methodology described above and to test the hypotheses of the theories presented, using quarterly time series of real GDP, inflation and unemployment in the Czech Republic.

\subsection{Data}

Several facts make it rather difficult to achieve our aim. Firstly, it can be very difficult to define the political dummies in the Czech case, especially for the partisan theories as the Czech Republic has a relatively short history of democracy. The second problem that makes it difficult to test the political cycle theories in the Czech case is that we currently have only short time series of the requisite economic variables. In the cases of inflation and unemployment, data are available from 1993, whereas for GDP the series starts as late as 1996. Moreover, these variables are affected by the significant structural changes that the Czech Republic experienced in the 1990s. Typical examples include the sharp rise in the Czech unemployment rate between 1996 and 1999 and the gradual fall in inflation from above 20\% in 1993 to its current low levels. As the result these economic variables have quite different dynamics in comparison with other EU countries. The development of real GDP is at the same time influenced by the process of economic convergence. The general unemployment rate, real GDP and inflation are plotted in the following charts.

6 Extraordinary elections after the government resigned; a caretaker government headed by Josef Tošovský was in power for six months.

7 The government that was in power until 1998 was regarded essentially right wing, as the main incumbent portrayed itself as a right wing party, whereas in 1998-2006 a broadly left wing government was in power (the main ruling party being the Czech Social Democratic Party, CSSD). The electoral deadlock after the 2006 parliamentary elections led to several months of fruitless negotiations on forming the new government. The new government - composed of representatives of centre right political parties - did not win a vote of confidence until January 2007. 
Figure 1

General Unemployment Rate (in \%), Annual and Quarterly Changes in General Unemployment

Rate (in percentage points), except for annual changes, data seasonally adjusted by X12

Arima method

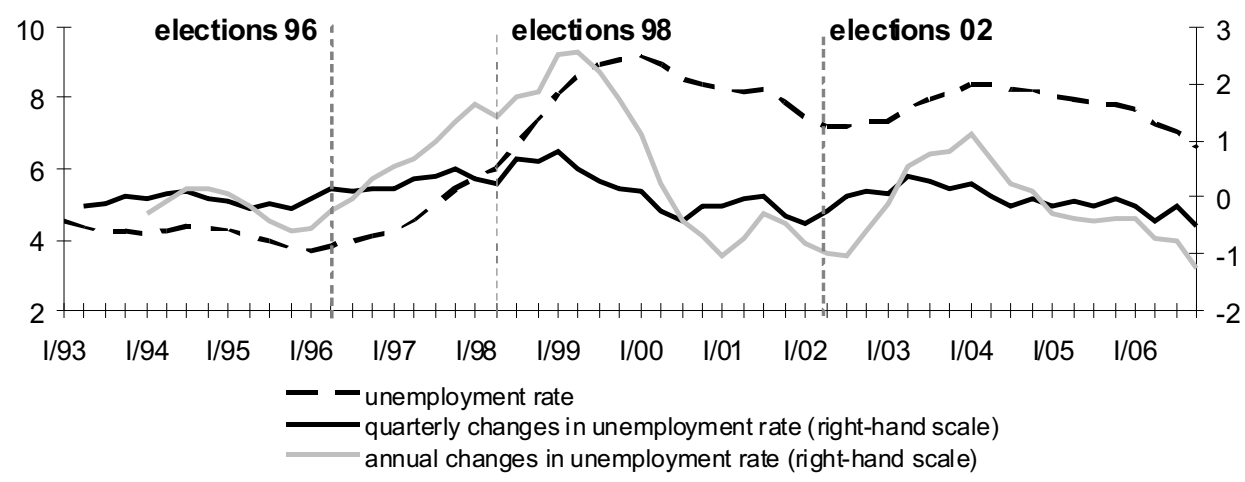

Source: Czech Statistical Office and author's calculations

Figure 2

Annual and Quarterly Changes in Real GDP (in \%, quarterly changes from seasonally adjusted data - X12 Arima method)

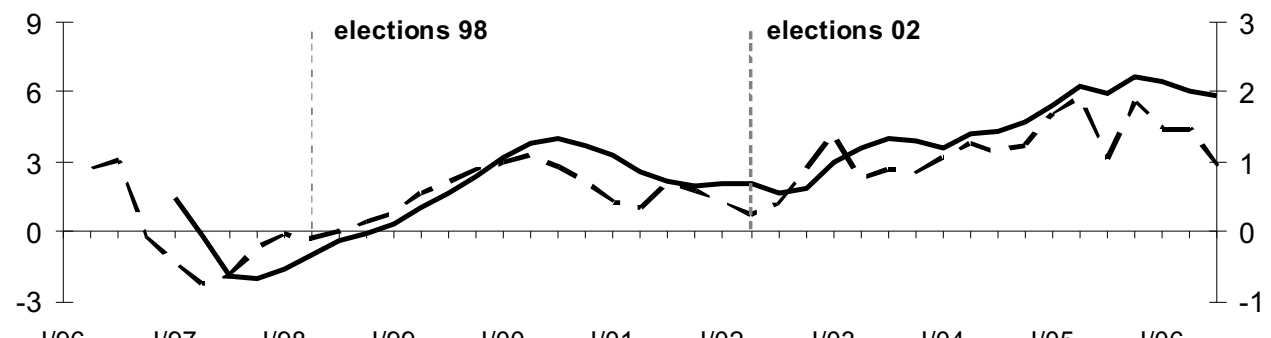

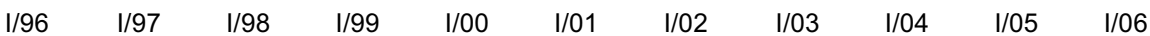

Source: Czech Statistical Office and author's calculations

Figure 3

Annual Headline, Net and Adjusted Inflation (measured by CPI, in \%)

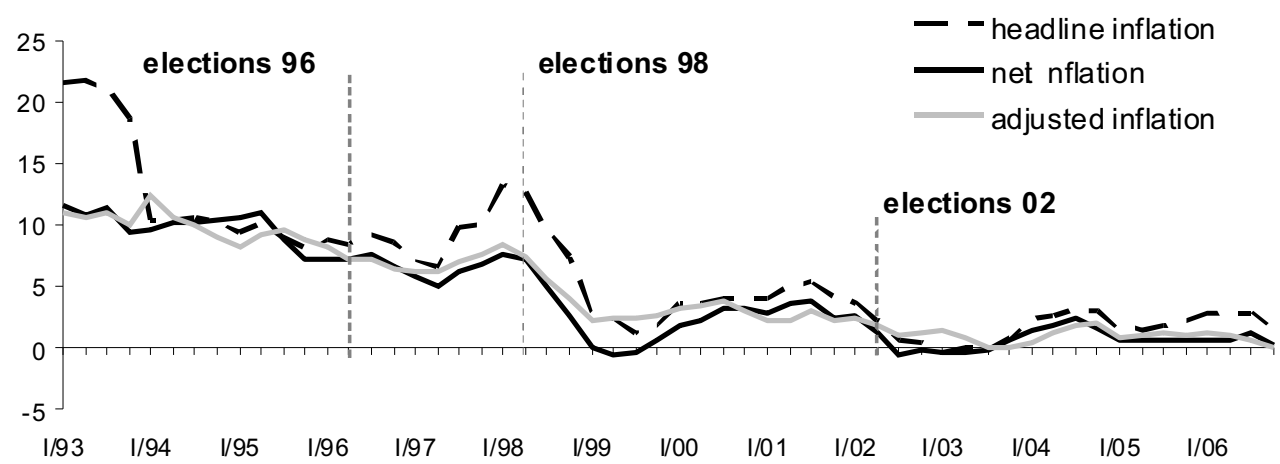

Source: Czech Statistical Office and author's calculations 
Figure 4

Quarterly Headline, Net and Adjusted Inflation (measured by CPI, in \%)

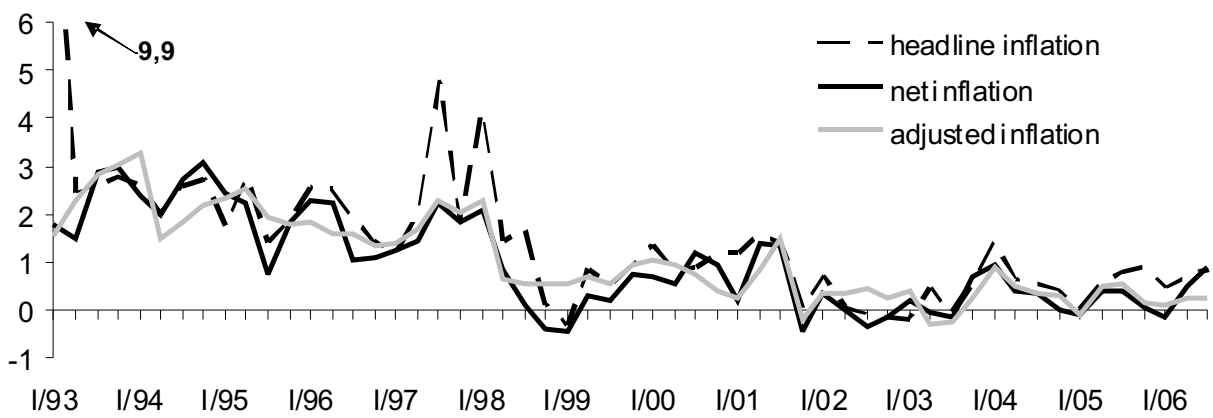

Source: Czech Statistical Office and author's calculations

Real GDP, the unemployment rate and the HICP in the EU- 15 were chosen as proxies for the world economy. In the case of the HICP for the EU-15, however, Eurostat provides a comparable time series from 1996 only; this considerably reduces the number of observations. Given the already relatively short time series in the Czech Republic, this shortening of the time interval is less than ideal, so in the end no world proxy was included in the model for the test of inflation. Unfortunately there is no other proxy routinely available for quarterly inflation in the EU-15 over the entire period under review.

\subsection{Stationarity Testing and the Perron Trend Stationarity Test with a Structural Break}

As mentioned above, testing the political cycle theories using AR models requires stationary time series. According to the ADF (Augmented Dickey Fuller) test, however, the time series of real GDP, the unemployment rate and the consumer price index appear to be non-stationary. ${ }^{8}$ Applying quarterly or annual differences to stationarize the time series does not eliminate the non-stationarity in the cases of real GDP and the unemployment rate. ${ }^{9}$ One reason for this is that they have relatively problematic profiles owing to the ongoing transformation of the Czech economy.

By contrast, the time series of quarterly changes in the CPI (seasonally adjusted by the X-12 Arima method) displays trend stationarity. The inclusion of the trend ensues from the fact that up until 1998 in particular, the transformation of the Czech economy was accompanied by a gradual adjustment of the price level and a gradual decline in the inflation rate. Tests were also performed on the time series of quarterly changes in net and adjusted inflation, which, due to the exclusion of some volatile items ${ }^{10}$, have less

8 The most appropriate model for testing the null hypothesis of non-stationarity was chosen on the basis of the usual diagnostic tests and criteria.

9 Quarterly differences were applied to the series seasonally adjusted by the X-12 Arima method.

10 Net inflation excludes regulated prices and administrative changes (e.g. tax changes). Adjusted inflation is net inflation adjusted for food prices. 
dramatic profiles, especially up until 1999. As with headline inflation, the ADF test rejected the null hypothesis of non-stationarity at the 5\% significance level for both these series (although only for the shortened series starting in 1995).

As the problem of non-stationarity of the time series of the first differences of real GDP and the unemployment rate is also present in numerous other countries, several recommendations have been made regarding this issue. One of the proposed solutions is to test the political cycle hypotheses using the time series of the differences in the relevant variables between the country under review and the world average. These differences might show stationarity and moreover are recommended in the present model to control for the effect of the world economy on the variable. In the Czech Republic, these differences were defined as the difference between the Czech variable and the EU-15 average. In the case of unemployment, however, the non-stationarity problem arises even for the time series defined in this way, as it recorded sharp growth in 1996-1999, unlike in the EU-15 (see Figure 5). This result implies an absence of strong links between the labour markets in the Czech Republic and the EU-15, owing to low international mobility of workers. Under these circumstances there is no strong justification for including a world proxy in the model.

Figure 5

Differences between the Czech General Unemployment Rate and the EU-15 Average (in percentage points)

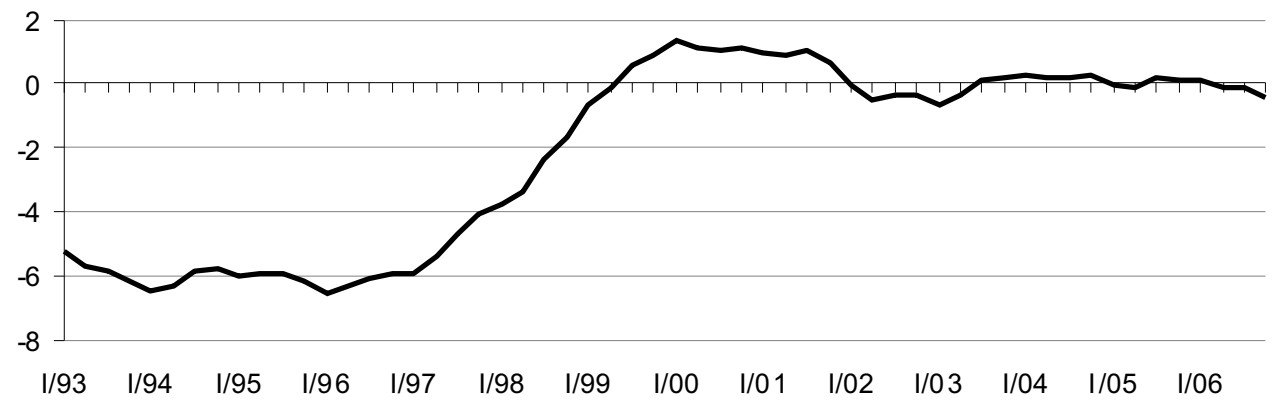

Source: Czech Statistical Office, Eurostat and author's calculations

In the case of GDP, by contrast, the time series of the differences between annual real GDP growth in the Czech Republic and average real growth in the EU-15 is trend stationary at the $5 \%$ significance level. ${ }^{11}$ Including the trend in the tested equation is consistent with the hypothesis that the Czech economy is going through a period of economic convergence towards the advanced EU countries, which, however, have recently been experiencing flat or negative growth. From 2000 onwards one can thus see a steady rise in the differences between Czech annual real GDP growth and the EU-15 average (see Figure 6).

11 On the basis of the diagnostic tests, the equation excluding the lagged differences containing the trend and the constant was determined as the most appropriate for testing for a unit root using the ADF test. 
Figure 6

Differences between Czech Annual Real GDP Growth and the EU-15 Average (in percentage points)

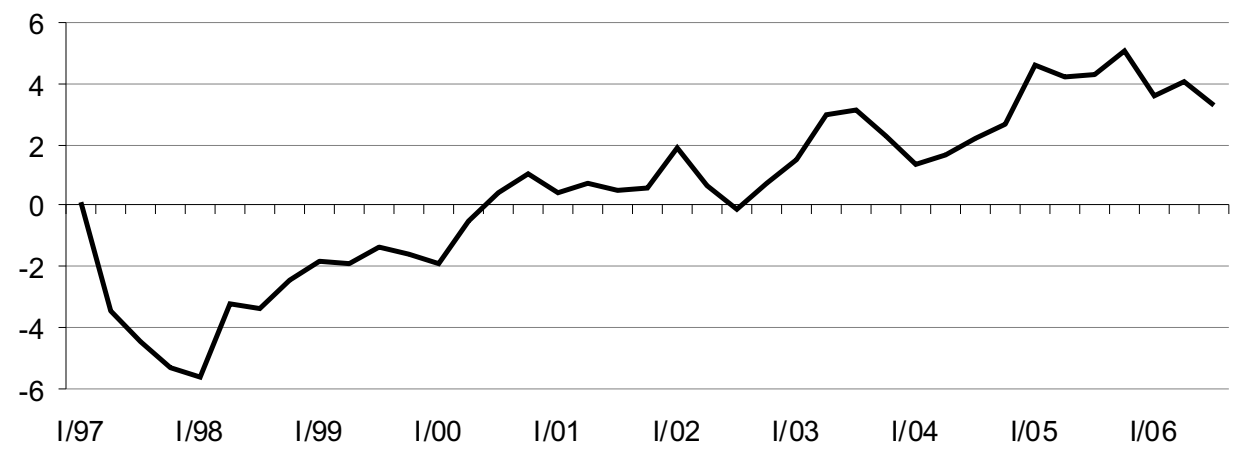

Source: Czech Statistical Office, Eurostat and author's calculations

Other potential solutions can be tried if we do not want to give up on the idea of testing for a political cycle using the unemployment rate when the application of the usual recommendations for eliminating time series non-stationarity does not help us to identify the stationarity condition. One option is to shorten the unemployment rate time series by excluding periods in which major structural breaks occur. For example, the time series of quarterly changes in the unemployment rate for the period of 1999-2006 is on the verge of rejection of a unit root. Generally, though, we cannot regard the unemployment rate time series defined in this way as unambiguously stationary. Moreover, shortening the time series any further prevents it from being used to test for a political cycle in the way described above.

A further method for overcoming the problem of the presence of a unit root in time series containing a structural break provided Perron (1989). He developed a technique for testing for a unit root of a time series based on an augmented version of Dickey and Fuller's standard method where the alternative hypothesis is trend stationarity of the tested series. The method allows for the presence of an exogenous structural shock in the trend function (in the form of either a shift in its level or a change in its slope). The null hypothesis is that the tested time series $\left\{y_{t}\right\}_{0}^{T}$ contains a unit root with drift and that an exogenous structural break occurs at time $T_{B}\left(1<T_{B}<T\right)$. Because Perron's approach assumes that the structural break is exogenous, the time at which it occurs needs to be determined in advance. The alternative hypothesis is that the series is stationary about a deterministic time trend with an exogenous change in the trend function at time $T_{B}{ }^{12}$ Perron considered three parameterizations of the structural break under the null and the alternative (for details see Perron, 1989). The actual unit-root testing under Perron's approach is based on the following models:

12 Perron's technique was subsequently developed by Zivot and Andrews (1992). They rejected the assumption of an exogenous breakpoint (as have numerous other authors - see Zelhorst and Hann, 1995) and developed a unit-root test allowing for an endogenous break in the trend function. 
Model (A): $y_{t}=\mu^{A}+\theta^{A} D U_{t}+\beta^{A} t+d^{A} D(T B)_{t}+\alpha^{A} y_{t-1}+\sum_{i=1}^{k} c_{i} \Delta y_{t-i}+e_{t}$,

Model (B): $y_{t}=\mu^{B}+\beta^{B} t+\gamma^{B} D T_{t}^{*}+\alpha^{B} y_{t-1}+\sum_{i=1}^{k} c_{i} \Delta y_{t-i}+e_{t}$,

Model (C): $y_{t}=\mu^{C}+\theta^{C} D U_{t}+\beta^{C} t+\gamma^{C} D T_{t}+d^{C} D(T B)_{t}+\alpha^{C} y_{t-1}+\sum_{i=1}^{k} c_{i} \Delta y_{t-i}+e_{t}$,

where $D(T B)_{t}=1$ if $t=T_{B}+1, D U_{t}=1$ if $t>T_{B}$ and $D T_{t}^{*}=t-T_{B}$ and $D T_{t}=t$ if $t>T_{B}$. Otherwise $D(T B)_{t}, D U_{t}, D T_{t}^{*}$ and $D T_{t}$ are 0 . Model (A) tests a null hypothesis of presence of unit root permitting exogenous change in the level of the series against the trend-stationary alternative which allows for a one-time change in the intercept of the trend function. Model (B) tests the null hypothesis of existence of unit root with constant drift against the alternative hypothesis of trend-stationary process with a change in the slope of the trend function. ${ }^{13}$ Finally model $(\mathrm{C})$ tests a combination of both effects taking place simultaneously. The null hypothesis of a unit root imposes the following restrictions on the selected parameters of the individual models: for Model (A): $\alpha^{A}=1, \beta^{A}=0, \theta^{A}=0$; for $\operatorname{Model}(\mathrm{B}): \alpha^{B}=1, \gamma^{B}=0, \beta^{B}=0$; and for Model (C): $\alpha^{C}=1, \gamma^{C}=0, \beta^{C}=0$. Under the alternative hypothesis of trend stationarity, $\alpha^{A}, \alpha^{B}$, $\alpha^{C}<1 ; \beta^{A}, \beta^{B}, \beta^{C} \neq 0$; and $\theta^{A}, \theta^{C}, \gamma^{B}, \gamma^{C} \neq 0$. At the same time, coefficients $d^{A}$ and $d^{C}$ should be close to zero, whereas under the null hypothesis they are expected to be significantly different from zero. In other words, to accept the alternative hypothesis of trend stationarity of the series under any of the aforementioned models, coefficient $\alpha$ must be significantly less than one and the trend variables included in the model and representing the exogenous shock in conformity with the alternative hypothesis must be statistically significant. To assess coefficient $\alpha$, Perron estimated specific tables of critical values of the t-statistics (for details see Perron, 1989).

The general unemployment rate recorded a structural change during the period 1996-1999, when the unemployment rate gradually rose from around 4 per cent to around 9 per cent. The increase of the unemployment rate was caused by combination of two factors. On the one hand, the strong generations of 1970 s joined the economically active population and at the same time the economic problems in the regions with continuing slump of major industrial sectors deepened (it was accompanied by sales problems, inconvenient structure of qualification of unemployed people, etc.). Since 2000 the unemployment rate has been fluctuating in the range of 7-9 per cent with a slight downward cyclical tendency. The change after the year 1999 was connected with gradual decrease of labour supply in the situation of stagnant labour demand. The year 1999 (specifically the first quarter of 1999) was therefore identified as the exogenous structural breakpoint.

In the case of the general unemployment rate time series, the results of the Perron trend stationarity tests confirmed the likelihood of the presence of a structural break in the slope of the trend function of this series, but the hypothesis of a one-time change in

13 Originally, the null hypothesis of model (B) permits change in drift but this specification does not allow for a proper testing of presence of a unit root. And hence Perron recommended the mentioned adjustment of null hypothesis (see details in Perron, 1989). 
the trend function was not supported. The test also rejected the presence of a unit root, i.e. it confirmed the alternative hypothesis of trend stationarity at the $5 \%$ significance level.

\subsection{Testing for a Political Cycle in the Czech Republic}

Based on the conclusions drawn in the previous section, the political cycle theories in the Czech case were tested using quarterly changes in the seasonally adjusted CPI, the time series of differences between annual real GDP growth in the Czech Republic and average real growth in the EU-15, and the general unemployment rate. As all these time series show trend stationarity, the Alesina and Roubini autoregression model for political cycle testing was augmented to include the trend (and, in the case of unemployment, the break in the trend).

The political dummies were defined in accordance with the theoretical concepts described in Section 2 and specified in detail in Section 3. In the case of the political dummies in the RPT and PT models, the quarter of the change of government was regarded as the quarter of parliamentary elections. As parliamentary elections in the Czech Republic are usually held in June and the government is appointed some time later, the third quarter is regarded as the quarter of elections for these variables. Although all the Czech governments to date have concentrated on transforming the Czech economy, a fact which has impaired their ability to implement their own policy programmes, the political dummies used in the models testing the RPTs and PTs were based on how the dominant parties in past governments portray themselves. ${ }^{14}$ In other words, for the purpose of the analysis ODS governments are regarded as right wing and CSSD governments as left wing.

The same problem does not arise in defining the political dummies for the testing of the opportunistic (PBC) theories, because these theories assume a common goal of re-election among all incumbents regardless of political affiliation. For these political dummies, each quarter during which elections actually took place is considered to be an election period. In the Czech case, elections traditionally take place in the second quarter.

The order of the autoregressive model for each variable tested was determined using the usual diagnostic tests and assessment criteria (Akaike info criterion and Schwarz criterion). In the case of GDP, a model with a dependent variable lagged by one and four quarters was chosen; in the case of inflation, lags of one and two quarters were included; and in the case of unemployment, lags of one to four quarters (or one to three quarters) were considered. In the case of the models for unemployment, potential slower adjustment of the labour market to new conditions was considered, and so various lag lengths were applied for the political dummies. In most of the models tested, however, the lagged political dummies were not significant. The exception was the one-quarter lag, but applying this generated very similar estimates as the models using non-lagged political dummies.

The results of the models testing the various political cycle theories in the Czech case partially supported the political business cycle hypotheses, which emphasize the opportunistic motives of politicians, with regard to both GDP and unemployment. The inclusion of the PBC political dummy in the models for GDP and unemployment was

14 The consequences of the "opposition agreement" between ODS and CSSD are not considered here. 
statistically significant at the $5 \%$ level, and the estimated coefficient had a positive sign in the case of GDP and a negative sign in the case of unemployment in line with the theoretical concept being tested. This implies that the economy was stimulated in periods before parliamentary elections, as reflected in higher GDP growth and a tendency for unemployment to fall temporarily.

In the case of GDP, however, this conclusion is not sufficiently strong, because the short GDP time series and the inclusion of an explanatory variable with four lags in the model meant that only the period from Q1 1998 to Q3 2006 was tested. Given that GDP in the pre-electoral period is being evaluated, the aforementioned assessment relates only to the 2002 and 2006 pre-electoral periods. In the case of unemployment, by contrast, the above conclusion is also supported by developments in the 1996 (or 1998) pre-electoral period. ${ }^{15}$

Estimated equations supporting the validity of the political business cycles hypothesis with regard to GDP and unemployment development have the following form:

$$
\begin{gathered}
\text { (1) } D I F_{-} H D P=-8.12+0.23 * t+0.36 * D I F_{-} H D P(-1)-0.39 * D I F_{-} H D P(-4)+0.66 * P B C \_8, \\
(-4.45) \quad(4.56) \quad(2.72) \\
\left(\mathrm{R}^{2}=0.94, \text { sigma }=0.67, \mathrm{~F}(4,30)=117.8[0.000]^{* * *}\right),
\end{gathered}
$$

(2) $U N E M=0.35+0.05 * t-0.06 * D T^{*}+0.89 * \operatorname{UNEM}(-1)+0.38 * \operatorname{UNEM}(-2)-$

$$
\begin{aligned}
& \text { (1.91) (3.67) }(-3.72) \\
& -0.72 * U N E M(-3)+0.29 * \operatorname{UNEM}(-4)-0.25 * P B C \_6, \\
& (-4.33) \quad(2.14) \\
& \left(\mathrm{R}^{2}=0.98, \text { sigma }=0.28, \mathrm{~F}(7,44)=292.7[0.000] * * *\right), \\
& \text { or: }
\end{aligned}
$$$$
\text { (3) } U N E M=0.42+0.04 * t-0.06 * D T^{*}+0.82 * \operatorname{UNEM}(-1)+0.44 * \operatorname{UNEM}(-2)-
$$$$
\text { (2.14) (3.35) (-3.50) (5.93) }
$$$$
-0.65 * \operatorname{UNEM}(-3)+0.24 * \operatorname{UNEM}(-4)-0.25 * P B C \_8 \text {, }
$$$$
(-3.88) \quad(1.79) \quad(-2.78)
$$$$
\left(\mathrm{R}^{2}=0.98, \text { sigma }=0.29, \mathrm{~F}(7,44)=287.3[0.000]^{* * *}\right),
$$

where $D I F_{-} H D P$ denotes the difference between real GDP growth in the Czech Republic and average growth in the EU-15, UNEM denotes the unemployment rate in per cent, $t$ represents the linear trend, $D T^{*}$ expresses the structural break in the trend function and PBC_6 and PBC_8 represent the political dummy for $\mathrm{N}=6$ and $\mathrm{N}=8$ respectively. The magnitudes of the estimated coefficients of political dummies correspond to results which were found out in the case of other countries (e.g. Alesina, 1990).

In the case of inflation, however, the PBC theory was not supported, as the results of the estimated model imply that the rate of growth of the price level decreased in the periods following the 1996, 1998 and 2002 parliamentary elections, whereas the theory predicts an upswing in inflation as a result of pre-electoral stimulation of the economy. This fact is clearly significantly affected by the overall profile of the inflation time series,

$15 \mathrm{~N}=8$ (or $\mathrm{N}=6$ ) seemed the most appropriate option for defining the political dummy. 
which has fallen continuously since 1993 to its current relatively low values. The estimated equation has following form:

$$
\begin{aligned}
& \text { (4) } S A \_M Q_{-} C P I=1.65-0.03 * t+0.26 * S A_{-} M Q_{-} C P I(-1)+0.12 * S A \_M Q_{-} C P I(-2) \\
& -0.58 * \mathrm{PBC}, \\
& (-2.55) \\
& \left(\mathrm{R}^{2}=0.58, \text { sigma }=0.73, \mathrm{~F}(4,48)=16.46[0.000]^{* *}\right),
\end{aligned}
$$

where $S A \_M Q \_C P I$ denotes the quarterly changes in the CPI (seasonally adjusted by the $\mathrm{X}-12$ Arima method), $t$ represents the linear trend and $P B C$ represents the political dummy.

As mentioned earlier, testing the partisan and rational partisan theories of political cycles is very difficult in the Czech case - partly because of the impaired ability of incumbents to implement their policy programmes during the Czech economic transformation, and partly because there was essentially only one change of majority incumbent party in the period under review - after the parliamentary elections in $1998 .{ }^{16}$ Prior to 1998 in particular, the Czech economy went through a transformation process associated with extensive structural changes in numerous macroeconomic indicators. In 1997 it was hit by a financial crisis. In recent years, though, the Czech Republic has been recording a very respectable growth tendency amid relatively low inflation. As a consequence, the results of the tests of the partisan theories are completely opposite to what the theoretical concepts would suggest.

The inclusion of a political dummy representing the RPT proved to be statistically significant for all the indicators studied. However, the signs of the estimated coefficients suggest that the change of government in 1998, when CSSD (which is regarded as a left wing party) came to power, led to temporarily lower GDP growth rates relative to the rest of the world as well as temporarily lower unemployment. A permanently lower price level was also recorded under the CSSD government. ${ }^{17}$ Given the aforementioned arguments, however, these conclusions, which contradict the RPT, cannot be regarded as definitive. It would be better to test the validity of the RPT/PT on the Czech business cycle after several further periods have elapsed, when the policies of the new government - and any future ones - have taken clearer shape.

\section{Conclusions}

The application of the Alesina and Roubini approach to the testing of the political cycle theories using selected macroeconomic variables in the Czech Republic partly supports opportunistic motives for the behaviour of Czech incumbents, i.e. the political business cycle theories. The test results reveal that partial economic recoveries occurred before

16 The effect of the change of government after the most recent elections in 2006 cannot be adequately tested on the data that are currently available.

17 However, a permanent impact of the change of government on GDP in accordance with the partisan theory was not confirmed. 
parliamentary elections, with a tendency towards higher GDP growth than in the EU-15 and a fall in the unemployment rate. By contrast, inflation contradicted the theory of the political business cycle models. This is probably due to the overall profile of the inflation time series during the economic transformation, which has fallen continuously since 1993 to its current relatively low values.

Partisanship in the behaviour of Czech incumbents was not supported. This fact, however, is probably a consequence of a limited ability to test the partisan theories in the Czech case, as there has essentially been only one change of majority incumbent party during the period of democracy. Moreover, the macroeconomic trends are strongly affected by the restructuring of the Czech economy during the 1990s. The economic and political measures adopted have thus been greatly influenced by the need to implement a series of reforms.

The key question associated with testing for a political cycle is to what extent the Czech government is able to influence the performance of the economy and to what extent its efforts ultimately affect macroeconomic indicators. Many economists who have studied political cycles argue that politicians have very limited ability to successfully manipulate the economy to increase their re-election chances (Brender and Drazen, 2004). But this does not mean that incumbents do not use fiscal policy to influence voting before elections, for instance by changing the composition of spending or manipulating transfers. Persson and Tabellini (2002), for example, identified political cycles in public spending, revenue and deficits for a data set encompassing 60 democratic countries. Regardless of the political system, they observed a general tendency to cut taxes before elections, whereas painful fiscal adjustments tended to be postponed until after the elections and were far less in evidence in all the economies tested.

It would certainly be interesting to perform further tests for a political cycle using the macroeconomic conditions in the Czech Republic in a few years' time, when a sufficient number of observations are available for all the variables under investigation. Scope is simultaneously opening up to apply alternative methods for testing for political cycles, for instance using fiscal variables. This is linked with a general shift in the current economic literature in this field towards studying political cycles primarily using fiscal variables, as the impact on output, inflation and unemployment is often questioned. One of the arguments for questioning the influence of the electoral cycle on macroeconomic indicators is the ambiguous conclusions of numerous papers on this issue (Rogoff, 1990). On the other hand, in the case of GDP there is support for the hypothesis that higher growth raises the probability of re-election in new democracies, but voters tend to be affected by growth over the entire period between parliamentary elections rather than in the election year itself (Brender and Drazen, 2005).

\section{References}

Alesina, A., Tabellini, G. (1990), "Voting on the Budget Deficit". The American Economic Review, 80 (1), pp. 37-40.

Alesina, A., Roubini, N. (1990), "Political Cycles in OECD Economies". NBER WP No. 3478, Cambridge, October 1990.

Andrikopoulos, A., Loizides, I., Prodromidis, K. (2004), "Fiscal Policy and Political Business Cycles in the EU”. European Journal of Political Economy, 20, pp. 125-152. 
Annett, A. (2005), “Enforcement and the Stability and Growth Pact: How Fiscal Policy Did and Didn't Change under Europe's Fiscal Framework". Paper prepared for Conference on New Perspectives on Fiscal Sustainability, Frankfurt, October 2005.

Bouthevillain, C., Cour-Thimann, P., Van den Dool, G., De Cos, P. H., Langenus, G., Mohr, M., Momigliano, S., Tujula, M. (2001), "Cyclically Adjusted Budget Balances: An Alternative Approach". ECB WP No. 77, September 2001.

Brender, A., Drazen, A. (2005), "How Do Budget Deficits and Economic Growth Affect Reelection Prospects? Evidence from a Large Cross-Section of Countries". NBER WP No. 11862. Cambridge, December 2005.

Brender, A., Drazen, A. (2004), "Political Budget Cycles in New versus Established Democracies". NBER WP No. 10539, Cambridge, June 2004.

Brender, A., Drazen, A. (2003), "Where Does the Political Budget Cycle Really Come From?" CEPR Discussion Papers, No. 4049.

Buti, M., van den Noord, P. (2003), "Discretionary Fiscal Policy and Elections: The Experience of the Early Years of EMU”. ECO/WKP No. 351, OECD.www.czso.cz.

Czech Statistical Office, www.czso.cz.

Drazen, A., Eslava, M. (2005), "Electoral Manipulation via Expenditure Composition: Theory and Evidence". NBER WP No. 11085, Cambridge, January 2005.

Drazen, A., Eslava, M. (2006), “Pork Barrel Cycles”. NBER WP No. 12190, Cambridge, April 2006.

Eurostat, http://epp.eurostat.ec.europa.eu.

Gärtner, M. (1994), "The Quest for Political Cycles in OECD Economies". European Journal of Political Economy, 10, pp. 427-440.

Hibbs, D. A. Jr. (1994), "The Partisan Model of Macroeconomic Cycles". Economics and Politics, 6 (March), pp. 1-23.

Hibbs, D. A. Jr. (1977), "Political Parties and Macroeconomic Policy". American Political Science Review, 71 (4), pp. 1467-1487.

Ito, T. (1990), "The Timing of Elections and Political Business Cycles in Japan". Journal of Asian Economics, 1 (1), pp. 135-156.

Kremer, J., Braz, C. R., Brosens, T., Langenus, G., Momigliano, S., Spolander, M. (2006), "A Disaggregated Framework for the Analysis of Structural Developments in Public Finances". ECB WP No. 579, January 2006.

Ministry of Finance, Czech Republic State Budget Act for 2007 and Documentation, www.mfcr.cz.

Nordhaus, W., D. (1975), "The Political Business Cycle". Review of Economic Studies, 42 (2), pp. 149-160.

Paldam, M. (1995), Political Business Cycles. Handbook of Public Choice. Oxford : Blackwell.

Perron, P. (1989), The Great Crash, the Oil Price Shock, and the Unit Root Hypothesis. Econometrica, 57 (6), pp. 1361-1401.

Persson, T., Tabellini, G. (2002), "Do Electoral Cycles Differ across Political Systems?" Seminar Paper, July 2002.

Persson, T., Tabellini, G. (2003), The Economic Effects of Constitutions. What Do the Data Say? Cambridge : MIT Press.

Persson, T., Tabellini, G. (2000), "Political Economics - Explaining Economic Policy". Cambridge : Massachusetts Institute of Technology.

Rogoff, K. (1990), "Equilibrium Political Budget Cycles”. The American Economic Review, 80 (1), pp. 21-36.

Rogoff, K., Sibert, A. (1988), "Elections and Macroeconomic Policy Cycles". Review of Economic Studies, 55 (1), pp. 1-16.

Veiga, L. G., Veiga, F. J. (2004), "Political Business Cycles at the Municipal Level”. NIPE WP 4/2004.

Zelhorst, D., de Hann, J. (1995), "Testing for a Break in Output: New International Evidence". Oxford Economic Papers, New Series, 47 (2), pp. 357-362.

Zivot, E., Andrews, D. W. K. (1992), "Further Evidence on the Great Crash, the Oil-Price Shock, and the Unit Root hypothesis". Journal of Business and Economic Statistics, 10 (3), pp. 251-270.

Žák, M. (1998), "Politicko-ekonomický cyklus" [The Political Economic Cycle]. Politická ekonomie, (4), pp. 471-480. 